\title{
Group Asylum, Sovereignty, and the Ethics of Care
}

\author{
Luis Xavier López-Farjeat ${ }^{1, *}$ and Cecilia Coronado-Angulo ${ }^{2, *}$ \\ 1 Faculty of Philosophy, Universidad Panamericana, Mexico City 03920, Mexico \\ 2 Department of Humanities, Faculty of Philosophy, Universidad Panamericana, Mexico City 03920, Mexico \\ * Correspondence: llopez@up.edu.mx (L.X.L.-F.); ccoronado@up.edu.mx (C.C.-A.)
}

Received: 11 June 2020; Accepted: 7 August 2020; Published: 12 August 2020

\begin{abstract}
It is assumed that the states have the right to control their borders and decide whom they want to exclude, isolate, ban, or impose restrictions on. Although it seems that the problematic notion of "sovereignty" gives the state the right to make these kinds of decisions, there are situations where ethical duties to other human beings supersede sovereignty and where, in fact, those ethical duties limit sovereignty. This would be the case of group asylum situations. In this paper, we propose Axel Honneth's ethics of recognition as a complement to the liberal notion of solidarity. By introducing a derivation of the ethics of recognition, namely, the "ethics of care," we argue that our connection to others and the ethical duties we have with them impose some limits on the idea of sovereignty.
\end{abstract}

Keywords: migration; group asylum; sovereignty; ethics of recognition; ethics of care; solidarity; Axel Honneth; Jürgen Habermas

\section{Introduction}

Intense debate abounds in the public sphere concerning the regulation of borders and the way in which states should treat migrants. Recent migrant "crises" in different parts of the world have once again brought up the question of the duties states have toward migrants. It is assumed that liberal democracies should have inclusive migratory policies since they are built upon universal ethical principles: Moral equality among human beings, respect of individual human rights and freedoms, and the idea that people should not be discriminated against on the grounds of their gender, sexual orientation, race, nationality, or religion. Yet, as we see so often, liberal democracies do not always act in accordance with these principles. Quite often, immigration controls disregard and disrespect human rights, especially when large groups of people who, for some reason have been forced to leave their places of origin, are concentrated at the borders, and exceed the state's administrative capacities to react appropriately. These groups of displaced people and asylum seekers are often seen as a danger to the country they wish to enter, and consequently, it is common for states to tighten border controls (for a discussion on border controls from the perspective of global ethics, see Camacho 2019).

The ethical criteria by which border controls are established are not frequently discussed in the scholarly literature on the ethics of immigration. Some exceptions, among a few others, are Carens $(1987,2013)$ and Fine $(2013)$. Caren's argument leads to the conclusion of opening borders (see also Cole 2012, 2016; Abizadeh 2008). We do not think, however, that the ethical approach to border controls necessarily leads to prescribing open borders. Fine evaluates the "moral justifications" for immigration controls, questioning the right of the state to exclude, but she does not provide a specific ethical model, as we will do, to face that question. As she mentions, there is a general assumption that states have the right to choose whom they want to admit, and it is generally granted that they even have the right to ban entry of migrants (Blake 2013, 2014). This does not mean, however, that there should be no discussion concerning the ethical grounds on which those decisions are made. It seems, however, that raising ethical constraints on border controls would limit the state's sovereignty. It is 
difficult to provide a sufficiently broad definition of "sovereignty" and, in fact, it is a problematic concept widely discussed in scholarly literature (Zaum 2007, pp. 27-50; Waltermann 2019). Here, we understand the term as the excersising of supreme authority over a political entity territorialy defined. There is nothing easy about establishing how the liberal ideal of moral equality and respect for universal human rights can be harmonized with this idea of state sovereignty and democratic self-determination (Benhabib 2017, p. 24; Miller 2007, pp. 163-200; Stilz 2019, pp. 187-215). Benhabib points out, for instance, that in many cases the states interests sacrifice the right to universal hospitality. Hence, she argues that liberal democracies "need to decriminalize the world wide movement of people and treat each person, whatever his or her political citizenship status, in accordance with the dignity or moral personhood" (Benhabib 2004, p. 177).

Jürgen Habermas, a German sociologist and philosopher, is among those who have discussed this delicate balance. He asks how states can preserve their sovereignty, and, at the same time, commit to respecting universal obligations that transcend their borders. Do states have special duties towards migrants? According to Habermas, special duties arise among persons who are considered members of a common group or society. This is the case of relationships that imply proximity among different persons as happens, for instance, with family, friendship, or the interaction among neighbors or fellow citizens of a political community. In these kinds of relationships, there are positive duties that are indeterminate because it is impossible to quantify the degree of support and solidarity among the members of these communities (Habermas 1996, p. 510). These positive duties happen, according to Habermas, within the social boundaries of a political community. Habermas conceives that even the state can be considered a legal community in which ideally special duties among its members exist. With this in mind, it is unclear what kind of duty the state has towards non-citizens, foreigners, and migrants, given that they could be considered alien to the political community, or they can be considered as members of the political community with different rights, or sometimes without citizen rights.

Are liberal democracies obliged to adopt, in accordance with their principles, an inclusive attitude towards migrants? If the answer is affirmative, do states have the right to select whom they want to include or even to exclude and ban the entry of large groups of migrants, displaced people, or asylum seekers? On what ethical grounds do they make these kinds of decisions? In the first section of this paper, we discuss some of the most common arguments to justify border controls, and argue that, while they do not take into consideration some sort of ethical grounds, they could disregard and disrespect human rights. We also question the cases in which migrants are accepted for utilitarian reasons alone. In the second section, we shall argue that Honneth's ethics of recognition raises the relevance of complementing liberal democracies' inclusion practices, especially the idea of solidarity, by introducing what he calls the "ethics of care," which ideally could provide the ethical grounds to which we have referred. The ethics of recognition is an ethical theory according to which we shall recognize the personal autonomy of all human beings, their freedom, their personal identity, and their personal expectations. Moreover, it considers intersubjectivity, that is, the capacity to share our human experiences with others, as the appropriate process for personal self-realization. This ethical model does not limit the scope of human relations to the institutional framework designed by legal principles, but rather expands the spheres of recognition towards moral attitudes such as empathy, affection, or care. The ethics of care is a derivation of the ethics of recognition from which can be argued that our connection to others and the ethical duties we have with them are based on a common humanity which entails benevolence and compassion.

The ethics of care presupposes an ethical attitude according to which we act considering the welfare of others since our own welfare and the collective welfare itself depend on our relationships with others. This ethical attitude does not nullify the sovereignty of the state, although it does limit its power, especially in cases where the protection of human rights and the integrity of vulnerable people is a priority. Although sovereignty gives the state the right to decide to not admit migrants, there are situations where ethical duties to other human beings supersede sovereignty and where, 
in fact, those ethical duties limit sovereignty. A situation of this kind would be the case of group asylum. We shall argue in the same second section that, beyond solidarity and equality, liberal democracies should act according to the ethics of care. Finally, we will conclude discussing the kinds of limits the ethics of care imposes on state-based sovereignty. We shall explain why those limits are not necessarily negative, but rather contribute to the strengthening of liberal democracies.

\section{Common Arguments to Justify Border Controls}

Friman and Hidalgo (2016) have argued that one can accept liberalism or substantive immigration restrictions, but not both. This dilemma can be posed in the following way: If the state's sovereignty grants it the powers to restrict immigration, then it also grants it the power to restrict liberal freedoms. It would be somewhat ambitious to exhaustively discuss here the moral foundations of liberalism. Several philosophers, from John Locke and John Stuart Mill to John Rawls and Jürgen Habermas, have carried out that work. In this paper, we limit ourselves to a fundamental liberal principle, namely, the freedom to migrate, which is widely recognized as a basic liberal liberty, along with freedom of speech, freedom of religion, freedom of association, and others.

The freedom to migrate is a variant of the freedom of movement. The freedom to migrate is part of the right to free circulation, not only internal circulation, but also the right to transiting through other countries and even to apply for residence or asylum. Nevertheless, international circulation is not that simple since different countries assume they have the right to control and restrict the admission of migrants to their territory. States select whom they want to include in their communities and who they can exclude, isolate, ban, or impose restrictions on. For instance, states assume they have the right to impose restrictions on criminals and terrorists, to ban entry to large groups of poor people, or to control their borders in case of pandemic. In these cases it could be argued that there is a security threat (Carens 2013, p. 175). However, there are other cases in which other criteria, for example, race, culture, or religion are used to exclude prospective migrants. Several scholars (Walzer 1983; Miller 2005, 2007, 2016, pp. 222-24; Meilaender 2001, pp. 81-103) have argued that states have the right to decide, shape, develop, and control the kind of community they want and, with this in mind, should select citizens that share common moral and cultural values because such commonality may contribute to greater social cohesion. It needs to be discussed, however, whether selection criteria for the sake of preserving social cohesion shall consider some kind of ethical grounds. There is a wide variety of arguments made to justify that the state actually has the right to select, exclude, or ban migrants. The most common are related to the preservation of cultural identities and the protection of sovereignty and national security.

Some scholars have defended the importance of cultural identities as a "primary identification focus" based on the sense of belonging (Margalit and Raz 1990). In this same direction, the meaning of belonging is seen as an element that reinforces the dignity and identity of individuals and that, when institutions are shaped by a culture with which people are familiar, it facilitates the participation of citizens in the public life of their communities (Tamir 1993; Blake 2008, pp. 974-75). It is true that sometimes shared values or similar ways of thinking may contribute to coexistence and neighborliness among the citizens of a country. In contrast, people with a strong sense of cultural or national identities think that persons with other cultures, customs, or religions could "contaminate" their families or their communities. Cultural differences thus become a strong reason to justify the selection and even the ban of migrants.

Being part of a cultural identity makes people aware of their roots and their legacy. Celebration of a cultural identity and the sense of belonging to it are not necessarily reprehensible. Nevertheless, this can easily develop into the defense of essentialist identities and exclusionary nationalisms, as well as discriminatory discourses and practices aimed against migrants, foreigners, and local minorities and indigenous groups. While it is true that fulfillment is largely linked to people's sense of belonging to a tradition, a nation, and in some cases to a religion, said belonging can also be an obstacle for recognizing, respecting, and living peacefully with other cultures. 
Those who defend the need to tighten immigration controls to protect a cultural identity disregard the positive effects of cultural diversity. It is not true that cultural diversity impedes the preservation of traditions. A great tradition can always coexist and subsist along with other cultures and traditions. In fact, many migrant communities have integrated without difficulty in host countries, preserving their cultural values and idiosyncrasies, while simultaneously adapting to the new cultural environment. In many cases, the interaction between different traditions and cultures not only opens up an opportunity to empathize with other human beings, but also enriches people through their own experiences. Clearly, encounters with diversity may generate some confrontation. There will be cases in which integration processes are not so peaceful. While they will not be exempt from difficulties, liberal democracies have the capacity to promote multicultural integration policies. Conflict is normal in human societies. For this reason, social actors have a crucial job in promoting resolutions that reduce conflict, respect human rights, and preserve peace and social coexistence.

Many people argue that the presence of migrants decreases public safety and increases crime rates. However, the social science literature shows this to be false (take as an example the US-Mexico border, usually perceived as violent, and see Castañeda and Chiappetta (2020) in this special issue; Armenta (2017)). When states do not have the economic and social conditions to guarantee migrant insertion into the community to which they arrive, there is a risk that they will join marginalized sectors that lack access to education, health services, and jobs. Migrants, therefore, are vulnerable to becoming criminals and to be recruited by criminals, terrorists, drug dealers, etc. It is often forgotten that migrants are often exploited and denigrated, and that their integrity and human rights are continually violated, either by migration authorities or by criminals. In cases where it is possible to integrate migrants on a regular basis into society, their situation is still difficult: Some people think that migrants take away opportunities to study or work from nationals. However, as we will see, despite the rejection of their presence, several social scientists have highlighted migrants' impact on the economic and labor spheres as something positive.

Migration can benefit nationals in the labor market. Several economists recognize that the economic effect of migration on the economy is positive because the number of jobs available in an economy is not fixed. Several economists believe that migrants' presence in the labor market encourages employers to engaged in activities that are more labor-intensive. Migrants may not compete with nationals in the labor market because they are concentrated in some types of jobs (Ho and Ariss 2018; Jawetz 2019). All this implies that migration can increase the number of jobs. An example of this is Turkey, which in 2013 ranked 71 (out of 185) in the list of countries with the greatest ease of doing business (Doing Business 2013). In 2018, Turkey moved to position 60 (Doing Business 2018). The presence of more than two and a half million Syrian refugees has led to the installation of a growing number of companies with Syrian capital. This does not mean that some Syrian migrants have not had integration problems. Unfortunately, the poor have the hardest time adapting. As Adela Cortina (Cortina 2020) has pointed out, often times the rejection of immigrants and refugees is a rejection of poor people.

It is true that entry and acceptance for migrants who are highly educated and coming with large economic resources are simpler than for migrants in poverty. Central American migrants' presence in Mexico, for example, is seen as a problem for both the Mexican and U.S. governments precisely because they are low-income people. Adela Cortina coined the term "aporophobia" to designate rejection, fear, and contempt for the poor. It is true that our societies are not empathetic with poor people, who are among the most discriminated sectors. A question is whether a country should care for poor migrants rather than take care of citizens in similar conditions. This dilemma has become a serious concern, for example, in the recent situation at Mexico's southern border. In January 2020, an enormous group of migrants and asylum seekers was blocked by Mexican National Guard troops, while several Mexicans supported the government's decision. It is difficult for many citizens to understand that, although local poverty reduction should be a priority in any democratic society, states cannot avoid responsibility to migrants. 
We agree with Adela Cortina that we should think about the means that both government and civil society should develop to include migrants: The dignity of every person demands a minimum of justice (Cortina 2020, pp. 125-48). Any immigration policy should consider these demands for justice, and we argue that the relationship with migrants should not be reduced to the concern for justice. It should be based on an ethics of recognition. The first step to introduce the ethics of recognition is to abandon the idea, which appears in several economic approaches to migration, of a utilitarian relationship with migrants. Habermas explains the attempt to justify special duties with migrants from a utilitarian perspective. Economistic views are based on the benefits that migrants can offer. The problem is that the utilitarian model becomes discriminatory: There would be no need to help those migrants that are unable to contribute anything to the receiving country (sick people, children, elderly, etc.). The utilitarian stance would force, as Habermas observes, the institution of a migratory policy that only allows access to those whose presence would not unbalance the economic stability of a country. Clearly, in this case, the selection criteria are discriminatory. It should be noted, however, that several countries take these criteria into consideration when selecting or excluding migrants.

Scholarly literature has discussed the legitimacy of selecting migrants according to the distinction between high-skilled migrants and low-skilled migrants (Lim 2017; Fine 2016). This talent-based selection is also discriminatory. Note that the talent-based selection responds to a criterion of inequality between people, something that would not be expected from a liberal democracy. These kinds of distinctions argue that it is better to allow entry to a businessman or a scholar than to a poor person. This kind of selection is not feasible for group asylum sitations such as the ones we are currently facing both with Asian and African migration to Europe, and Central American migration to Mexico and the United States.

For a variety of reasons, in the past ten years, we have witnessed sizable migrations and forced displacements in different parts of the world: Violence, political and economic crises, famine, climate change, persecution and violation of human rights. Many people think that controlling, and even closing, borders is paramount to national security. Consequently, they expect governments to prevent migrants from entering. On the other hand, there are those who, despite the challenges of migration, realize that we are facing a humanitarian crisis and consider it a priority to protect people fleeing violence or other adverse conditions in their countries. For instance, in June 2019, Carola Rackete, a German Sea-Watch captain, rescued 42 migrants in Italian waters. She decided, acting discretionary, to enter the port of Lampedusa, and was immediately taken into custody by Italian authorities and was charged for violating a new law that prohibits aiding and abetting illegal immigration.

Matteo Salvini, the former Italian Interior Minister, and many other people considered Rackete a criminal. Rackete argued that she felt "a moral obligation," that the lives of those people were beyond "political games," and that she made her decision according to "the principle of human rights" (Kaschel 2019). The captain's actions clearly illustrate the tension between, on the one hand, a state that claims the priority of its sovereignty and, on the other hand, an ethical motivation that prioritizes respect for human rights and the care of vulnerable people. Rackete, without making it explicit, acted according to the ethics of recognition and care, the option that, as we shall argue, complements liberal democratic principles.

\section{The Ethics of Recognition}

Could it be possible to establish ethical grounds for selecting or excluding migrants, thus avoiding the violation of human rights and reacting adequately to large simultaneous claims for asylum and legal residency? Although it seems reasonable to prioritize human rights over states' sovereignty, we have seen, with the case of captain Rackete, that the relevant priorities are usually not entirely clear.

We propose that the ethics of recognition emphasizes our interconnectedness with other human beings, even when they are not part of our political community. As mentioned, this interconnection can be stated as follows: We shall act considering the welfare of others because our own welfare, as well as that of the collective, depends on our relationships with them. From this ethical standpoint, 
it can be inferred that migration is not an exclusively political and administrative matter, but rather transcends the idea about the sovereignty of the state because it is imperative to protect peoples' integrity and guarantee respect for their human rights. A basic premise in the ethics of recognition is the moral obligation to respect the dignity of every human being regardless of their race, gender, sexual orientation, nationality, and economic situation. It can be argued that any ethical or political theory shares this premise. The ethics of recognition, however, claims that human dignitiy is an intrinsic value in itself and the cornerstone of ethical decisions. This view stands in stark contrast to the utilitarian view that focuses on the social or economic consequences of ethical decisions neglecting the welfare of the concrete other. It is also contrasting with other ethical theories, as for instance, Marxism, in which there is a tendency to deny the role of individual rights, prioritizing the cooperative process of production as the means for integrating the citizens to the society (Honneth 2017, pp. 35-36). The hallmark of the ethics of recognition is, thus, the emphasis on human dignity over the consequences of ethical decisions.

The idea of "recognition" implies that every human being is able to recognize the common humanity of others. In short, the ethics of recognition establishes that when helping others, we help ourselves. However, this should not be seen as a utilitarian premise because, in this interdependence, concern for others is not motivated by our own welfare, but rather by the collective welfare. This means that, unlike utilitarian ethics, the ethics of recognition assumes that individuals are members of a collectivity and not isolated cells fixated on their own welfare. The ethics of recognition transcends the bounds of our political communities, is inclusive, it is cosmopolitan, it rejects discriminatory practices, and purports that we have special duties with migrants.

Habermas, for his part, sustained that human beings are part of a political community and thinks that special duties with the members of a political community exist. The members of a political community stand in solidarity with foreigners, according to Habermas, when they support new members' integration as long as they adopt the relevant social institutions and culture. In this sense, Habermas' conception of solidarity is not enough because it focuses on the welfare of the political community, and not on the welfare of foreigners, when what we need is a balance between both.

According to Habermas, the inclusion of every individual in practical discourse presupposes a symmetrical relation between members of a community. This is why he emphasizes that real "social integration" implies the adoption of institutional and cultural values in order to socially adapt. Honneth disagrees with Habermas' conceptualization of solidarity (Honneth 2007b, pp. 123-24). He believes that this understanding of solidarity leaves out cases where there is an asymmetrical relationship, such as those where people are "in such an extreme state of need or hardship that the moral principle of equal treatment can no longer be applied in a balanced manner. Therefore, human beings who are either physically or mentally unable to participate in practical discourses deserve at least the selfless care of those who are emotionally bound to them" (Honneth 2007b, p. 124).

Certainly, Habermas does not reject moral obligations with concrete others. He assumes that we should take care of the "welfare of one's fellow man," so he proposes a principle which he refers to as the "other of justice" (Habermas 1989). According to this principle, there is a concern for others that even extends into the affective sphere. Notwithstanding, Honneth points out that Habermas' concern for others presupposes the membership in "an ideal communication community," which allows for a "shared life context" (Honneth 2007b, p. 123), which should not be bound by political borders.

As Max Pensky has noticed, Habermas' social theory of communicative action locates the foundations of solidarity in a mode of communicative reason that transmits itself through modern social institutions. Habermas' theory of communicative action demands a high level of linguistic sophistication from citizens that implies social and cultural closeness among its members (Habermas 1984, pp. 99-101). In accordance with the communicative theory of Habermas, "'solidarity' means the bonding effect that arises in and through deliberating citizens, not in view of the contingent ethical bonds that obtain insofar as such citizens happen to be members of this particular society, but insofar as they have internalized and continually approve of just those norms constitutive for 
practice in any modern constitutional democratic society" (Pensky 2011, pp. 134-35). In this sense, Habermas underlines the crucial role of social institutions over the concrete other. Evidently, in liberal democracies, the role of social institutions is essential, but not sufficient. There are cases in which social institutions are weak or for some reason have ceased to exist. Consider, for example, the current situation of Venezuela and Syria, two cases in which there are governmental crises and, consequently, social institutions are not reliable.

To overcome the limitations of the Habermasian conception of solidarity, Honneth claims that the idea of the "other of justice" should be supplemented by the Levinasian-Derridian ethics of care (Honneth 2007b, pp. 118-24). For Levinas, in our encounters with other people, “( .. ) the other always faces me as a person in need of protection and concern to such a degree that I am overburdened in all my finite possibilities to act and thus concurrently become aware of a dimension of infinity" (Honneth 2007b, p. 118). Put it simply, our encounters with the others constitute a "face to face" moral experience. Derrida picks up this Levinasian notion of "face to face," and he "views the assymetrical obligation to provide unlimited care to another human being in his or her individual need as a central principle of morality" (Honneth 2007b, p. 119). The ethics of care, indeed, takes into consideration the asymmetrical responsibility towards the concrete other, rather than the solidarity limited to the supposed members of a shared communicative community (cf. Sinnerbrink 2011, p. 193). In short, solidarity is necessary, but a complementary and stronger moral attitude is needed, namely, care or help (Honneth 2007b, p. 101). This care is characterized by not seeking any payback or benefit. According to Honneth, most contemporary societies have forgotten moral attitudes in which we voluntarily attend to the concrete other, providing help and support, without considering reciprocal benefits (Honneth 2007b, p. 101).

From Honneth's ethics of recognition, we shall propose that the idea of "care" should be recognized as ethical grounds that need to be integrated into social institutions. The idea of care invites us to prioritize people's integrity and human rights over the sovereignty of the state. This does not imply, however, neglect of the political community. The ethics of care does not imply that states should renounce their sovereignty, but rather highlights that states' right to sovereignty has limits in so far as there are ethical duties to those outside one's particular political community precisely because our common humanity transcends those political communities. Importantly, the ethics of care should not be understood as a romantic or sentimental attitude. The ethics of care leads us to ask ourselves about our connections to and ethical duties with the rest of humanity, and it poses a true challenge to individualist and statist theories. As mentioned at the beginning of this paper, if the people living in liberal democracies want to take human rights seriously, they must understand that the sovereignty of states has limits. These limits should be understood as guidelines that indicate that beyond a specific normativity, in group asylum situations, states face an unusual circumstance where decisions should be made with extreme caution.

The ethics of care recommends carrying out a very careful deliberative process that takes into consideration both the capacity of each state to help, as well as the conditions of the migrants who wish to enter. Recently, Blake has related the ethics of care with the political virtue of mercy (Blake 2020, pp. 199-201). Both, mercy and the ethics of care, assume that states should undertake a rigorous self-assessment of their responsibility in making decisions regarding the destiny of migrants. Concerning these decisions, we must keep in mind that the primary goal is to actively help those who find themselves obliged to leave their lands, their homes, their countries. Hence, the ethics of care encourages reacting to the vulnerability of others, providing assistance according to the possibilities of each actor involved in defining immigration policy. Often, countries do not have the capacity to react in these deliberative processes and, consequently, the international community must be involved. Openness to the international community is characteristic of liberal democracies, and implies voluntary acceptance of certain commitments arising from international agreements.

Participation in these kinds of agreements means that sovereignty has its limits. These limits could be seen negatively insofar as they hinder the power of the state. Hence, some might think that 
proposing an ethics of care, which is characterized, as mentioned, by the relevance it gives to people and their human rights, could diminish the sovereignty of the state. Our proposal here is that far from diminishing the sovereignty of the state, the ethics of care and its strong commitment to human rights, as we shall see, strengthens and confirms that sovereignty.

Up to now, we have argued that the ethics of recognition leads to the idea of "care," and, in this direction, to an ethics that are focused on the protection of individuals, without diminishing political communities. We also argued that liberal democracies should admit this ethics of care as a guiding principle. Although it imposes limits to sovereignty, these limits are not necessarily negative. Actually, the ethics of care provide states with the opportunity to carry out a deliberative process that strengthens their sovereignty. This deliberative process certainly implies some tension between sovereignty and respect for human rights. There is a serious ethical dilemma when states must decide to the possible detriment of their sovereignty. Some scholars have even discussed whether the relation between sovereignty and human rights is antithetical (Cohen 2012, pp. 159-63). However, this collision, usually seen negatively, is not necessarily so. We wish to suggest that these collisions, tensions, and conflicts are positive and crucial for the maturity of liberal democracies. When states perceive migration as a challenge to their sovereignty, they must be aware that their decisions may define the future of many people. Therefore, states must exercise their authority responsibly, seeking greater possibilities or alternatives for resolution that do not reduce them to closing borders (thus turning their backs on the humanitarian problem), or simply opening borders indiscriminately.

When facing group asylum, liberal democracies meet the challenge of strengthening their liberal principles, both administratively and politically. From the administrative perspective, migration policies and asylum must be rethought. Migration institutions must be strengthened and, in particular, more regional development alternatives that involve the international community should be considered. Assuming these alternatives is a sign that states actually take on their role as the result of democratic decisions and aspirations for increased democraction in Tilly's (2007) sense of incorporating excluded residents and that they are really committed to protecting human rights. To remain indifferent to migrants' situations, or to avoid joint responsibilities to a problem that requires the involvement of various social institutions in each region, is to renounce the principles that sustain liberal democracies. As well as renouncing to a universal ethics from which we recognize ourselves as members of a human community sharing a common home, the planet Earth.

\section{Sovereignty and the Ethics of Care}

We have mentioned that there are cases in which migrants in vulnerable situations have been banned in some countries. This is, for instance, the case of the migrants protected by captain Rackete. As we mentioned, Italian authorities considered Rackete's action as a violation of the state sovereignty. She argued, however, as we explained, that she felt a moral responsibility to help those people. The Italian court - an arm of the state-absolved her, but public opinion was divided between those who considered Rackete's action as criminal, and those who were moved by her empathy with migrants. Instead of reacting according to liberal democratic principles protecting the integrity of individuals in a vulnerable situation, the former Interior Minister prioritized the protection of the state's sovereignty. In strictly legal terms, the Minister acted with legitimacy. In ethical terms, we could have expected a real concern for the care of the others. Liberal democracies should protect, as we have argued, not only the members of their political communities but also any vulnerable individual.

Liberal democracies cannot disregard helpless people who are trying to save their lives. Without ethical grounds for political and administrative decisions, the policies to address group asylum will become increasingly inhumane. Here, we have argued that the ethics of care can provide these ethical grounds. These ethics, which find their justification in the ethics of recognition, recommends that, in extreme cases, before thinking of applying solidarity, as Habermas would think, liberal democracies should act, as Honneth argues, according to the ethics of care. We have argued that this ethical model appeals to the recognition of a common humanity and claims that our connection 
to others and the ethical duties we have with them transcends the bounds of our own political communities and our institutional legal frameworks. As we have insisted, these ethics do not eliminate conflict and tension between the sovereignty of the states and respect for human rights, but they do contribute to coping with the conflict by considering it essential to the ethical and political development of human societies. According to Honneth, conflict is characteristic of liberal democracies. Struggle is what enables individuals to be recognized (Honneth 1995). As a matter of fact, it is the only way in which human beings shape their identities; the only way we realize that we are autonomous is by recognizing autonomy in the others (Honneth 2007a, pp. 130-31). Modern societies, according to Honneth, have forgotten the relevance of recognition. Honneth proposes a review and transformation of institutional practices, which are mainly instrumental, into humanized practices, confronting what he calls the "forgetfulness of recognition" (Honneth 2008, pp. 147-59).

As can be seen, Honneth's proposal has political intentions that surpass individual autonomy. These intentions consist in the insertion of the idea of "care" as an essential ethical attitude in the recognition of every human being, especially the most vulnerable among us. In our view, the idea of care challenges the state with an ethical obligation without diminishing its sovereignty. Instead, it strengthens democratic liberal principles since democracies (1) cannot remain indifferent to a problem as large in scale as group asylum; (2) cannot evade responsibilities by arguing that they are protecting their sovereignty; (3) must react to group asylum situations in consideration of the fact that care for individuals is a priority; (4) finally, in reacting to these kinds of situations, they must be involved in a deliberative process in which, administratively and politically, they sometimes must limit their sovereignty in order to respect and protect human rights.

Author Contributions: Conceptualization, L.X.L.-F. and C.C.-A.; methodology, L.X.L.-F. and C.C.-A.; investigation, L.X.L.-F. and C.C.-A.; writing-original draft preparation, L.X.L.-F. and C.C.-A.; writing-review and editing, L.X.L.-F. and C.C.-A.; project administration, L.X.L.-F.; funding acquisition, L.X.L.-F. Both authors have read and agreed to the published version of the manuscript.

Funding: This research was funded by Universidad Panamericana through the grant "Fomento a la Investigación UP 2019" Migración, territorio e identidades (UP-CI-2019-FIL-MX-05).

Acknowledgments: We are indebeted to the audiences of "Migration and Territory" seminar sessions, particularly with Enrique Camacho, Christa Byker, Adriana Ramírez, Carla Adell, Alejandro Arreola, Gustavo Duarte, and Tatiana Lozano. A previous version of this paper benefited from audiences at the Workshop "Migration, Territory and Identities," in which we received helpful comments from Michael Blake, Linda Bosniak, Paulina Ochoa, Eduardo Charpenel, Juan Espíndola, Enrique Camacho, and Camelia Tigau. We are also grateful to our students at the Seminar on Migration and Territory at Universidad Panamericana. We are particularly grateful to Ernesto Castañeda and three anonymous reviewers for their comments and critics.

Conflicts of Interest: The authors declare no conflict of interest.

\section{References}

Abizadeh, Arash. 2008. Democratic Theory and Border Cercion: No Right to Unilateraly Control Your Own Borders. Political Theory 36: 37-65. [CrossRef]

Armenta, Amanda. 2017. Racializing Crimmigration: Structural Racism, Colorblindness, and the Institutional Production of Immigration Criminality. Sociology of Race and Ethnicity 3: 82-95. [CrossRef]

Benhabib, Seyla. 2004. The Rights of Others. New York: Cambridge.

Benhabib, Seyla. 2017. Democratic Sovereignty and Transnational Law: On Legal Utopianism and Democratic Skepticism. In Critical Theory in Critical Times. New York: Columbia University Press.

Blake, Michael. 2008. Immigration and Political Equality. San Diego Law Review 45: 963-80.

Blake, Michael. 2013. Immigration, Jurisdiction, and Exclusion. Philosophy and Public Affairs 41: 103-30. [CrossRef]

Blake, Michael. 2014. The Right to Exclude. Critical Review of International Social and Political Philosophy 17: 521-37. [CrossRef]

Blake, Michael. 2020. Justice, Migration, E Mercy. New York: Oxford University Press.

Camacho, Enrique. 2019. Legitimate Exclusion of Would-Be Immigrants: A View from Global Ethics and the Ethics of International Relations. Social Sciences 8: 1-19. 
Carens, Joseph H. 1987. Aliens and Citizens: The Case for Open Borders. The Review of Politics 49: $251-73$. [CrossRef]

Carens, Joseph H. 2013. The Ethics of Immigration. New York: Oxford University Press.

Castañeda, Ernesto, and Casey Chiappetta. 2020. Border Resident's Perceptions of Crime and Security in El Paso, Texas. Social Sciences 9: 24. [CrossRef]

Cohen, Jean L. 2012. Globalization and Sovereignty: Rethinking Legality, Legitimacy and Constitutionalism. Cambridge: Cambridge University Press.

Cole, Phillip. 2012. Taking Moral Equality Seriously: Egalitarianism and Immigration Controls. Journal of International Political Theory 8: 121-34. [CrossRef]

Cole, Phillip. 2016. On the Borders of Solidarity: Ethics, Power and Immigration Controls. Soundings 63: 123-35. [CrossRef]

Cortina, Adela. 2020. Aporofobia, el Rechazo al Pobre. Un Desafío Para la Democracia. Barcelona: Paidós.

Doing Business. 2013. Available online: https://espanol.doingbusiness.org/content/dam/doingBusiness/media/ Annual-Reports/Foreign/DB13-Spanish.pdf (accessed on 27 May 2020).

Doing Business. 2018. Available online: https://espanol.doingbusiness.org/content/dam/doingBusiness/media/ Annual-Reports/English/DB2018-Full-Report.pdf (accessed on 27 May 2020).

Fine, Sarah. 2013. The Ethics of Immigration: Self-Determination and the Right to Exclude. Philosophy Compass 8: 254-68. [CrossRef]

Fine, Sarah. 2016. Migration in Political Theory: The Ethics of Movement and Membership. Oxford: Oxford Scholarship Online, pp. 1-32.

Friman, Christopher, and Javier Hidalgo. 2016. Liberalism or Immigration Restrictions, but Not Both. Journal of Ethics and Social Philosophy 10: 1-22. [CrossRef]

Habermas, Jürgen. 1984. The Theory of Comminicative Action. Translated by Thomas A. McCarthy. Boston: Beacon Press, vol. 1.

Habermas, Jürgen. 1989. Justice and Solidarity. Philosophical Forum 21: 32-53.

Habermas, Jürgen. 1996. Between Facts and Norms. Massachusetts: The MIT Press Cambrigde.

Ho, Giang, and Rima Turk Ariss. 2018. The Labor Market Integration of Migrants in Europe: New Evidence from Micro Data. Available online: https://www.imf.org/en/Publications/WP/Issues/2018/11/01/The-Labor-MarketIntegration-of-Migrants-in-Europe-New-Evidence-from-Micro-Data-46296 (accessed on 31 May 2020).

Honneth, Axel. 1995. The Struggle for Recognition: The Moral Grammar of Social Conflicts. Great Britain: Cambridge University Press.

Honneth, Axel. 2007a. The Other of Justice. In Disrespect: The Normative Foundations of Critical Theory. Cambridge: Polity Press.

Honneth, Axel. 2007b. The Social Dynamics of Disrespect: On the Location of Critical Theory Today. In Disrespect: The Normative Foundations of Critical Theory. Cambridge: Polity Press.

Honneth, A. 2008. Reification: A New Look at an Old Idea, with Judith Butler, Raymond Geuss \& Jonathan Lear. Edited by Martin Jay. New York: Oxford Univerity Press.

Honneth, Axel. 2017. The Idea of Socialism. Cambridge: Polity Press.

Jawetz, Tom. 2019. Building a More Dynamic Economy: The Benefits of Immigration. Testimony Before the U.S. House Committee on the Budget. Available online: https://cdn.americanprogress.org/content/uploads/2019/ 06/26065948/JawetzHouseBudgetTestimony2.pdf (accessed on 30 May 2020).

Kaschel, Helena. 2019. What Drives Sea-Watch Captain Carola Rackete to Rescue Migrants? DW News. Available online: https://p.dw.com/p/3LLI1 (accessed on 18 July 2020).

Lim, Desiree. 2017. Social Theory and Practice. Philosophy Documentation Center 43: 369-96.

Margalit, Avishai, and Jospeh Raz. 1990. National Self Determination. Journal of Philosophy 87: 439-61. [CrossRef]

Meilaender, Peter C. 2001. Toward a Theory of Immigration. New York: Palgrave.

Miller, David. 2005. Immigration: The Case for Limits. In Contemporary Debates in Applied Ethics. Edited by Christopher Heath Wellman and Andrew I. Cohen. Chichester: John Wiley \& Sons, pp. 193-206.

Miller, David. 2007. National Responsibility and Global Justice. Oxford: Oxford University Press.

Miller, David. 2016. Strangers in Our Midst: The Political Philosophy of Immigration. Cambridge: Harvard University Press.

Pensky, Max. 2011. Social Solidarity and Intersubjective Recognition: On Axel Honneth's Struggle for Recognition. In Axel Honneth: Critical Essays. Edited by Danielle Petherbridge. Leiden: Brill. 
Sinnerbrink, Robert. 2011. Power, Recognition and Care. In Axel Honneth: Critical Essays. Edited by Danielle Petherbridge. Leiden: Brill.

Stilz, Anna. 2019. Territorial Sovereignty. A Philosophical Exploration. New York: Oxford University Press.

Tamir, Yael. 1993. Liberal Nationalism. Princeton: Princeton University Press.

Tilly, Charles. 2007. Trust Networks in Transnational Migration. Sociological Forum 22: 3-24. [CrossRef]

Waltermann, Antonia M. 2019. Reconstructing Sovereignty. Switzerland: Springer.

Walzer, Michael. 1983. Spheres of Justice: A Defense of Pluralism and Equality. Oxford: Robertson.

Zaum, Dominik. 2007. The Sovereignty Paradox. The Norms and Politics of International Statebuilding. New York: Oxford University Press.

C 2020 by the authors. Licensee MDPI, Basel, Switzerland. This article is an open access article distributed under the terms and conditions of the Creative Commons Attribution (CC BY) license (http://creativecommons.org/licenses/by/4.0/). 